\title{
Effect of Nutrition on Deformation Disease in Gypsophila paniculata Mother Plants
}

\author{
Y. Ben-Yephet, M. Reuven, A. Zviebil, Y. Szmulewich, I. Lavkovits, T. Markovits, S. Soriano, and B. Bar-Yosef
}

First, second, third, and fourth authors: Department of Plant Pathology; and fifth, sixth, seventh, and eighth authors: Department of Soil Chemistry and Plant Nutrition, ARO, the Volcani Center, Bet Dagan 50 250, Israel.

Accepted for publication 8 March 2006.

\section{ABSTRACT}

Ben-Yephet, Y., Reuven, M., Zviebil, A., Szmulewich, Y., Lavkovits, I., Markovits, T., Soriano, S., and Bar-Yosef, B. 2006. Effect of nutrition on deformation disease in Gypsophila paniculata mother plants. Phytopathology 96:771-776.

Deformation disease of Gypsophila paniculata mother plants reduces cutting yields as much as $50 \%$ but does not kill the mother plants. In preliminary experiments, fertigation of $G$. paniculata mother plants with a 20:20:20 compound fertilizer ( $\mathrm{N}, \mathrm{P}, \mathrm{K}$, plus microelements) at an $\mathrm{N}$ concentration of $720 \mathrm{mg} / \mathrm{liter}$ reduced the expression of deformation disease compared with the conventional $\mathrm{N}$ concentration of $360 \mathrm{mg} / \mathrm{liter}$. The current study determined which component of the compound fertilizer reduced the disease. Experiments were carried out in 10-liter buckets packed with naturally infested 0 - to 8 -mm black tuff (Scoria $=$ crushed volcanic stones). Irrigation was applied once a day at 0.5 liter per bucket with the nutrient under test being added at 1.0 liter per bucket via the water once a week. Treatments included: (i) four levels of 20:20:20 fertilizer; (ii) four levels of each of N, P, K, and Fe-Zn-Mn mixture (ME) corresponding to their concentrations in the compound fertilizer; (iii) different $\mathrm{N}$ sources (20:20:20, $\left(\mathrm{NH}_{4}\right)_{2} \mathrm{SO}_{4}, \mathrm{KNO}_{3}, \mathrm{NH}_{4} \mathrm{NO}_{3}$, urea); and (iv) three pHs of the irrigation water at each of three $\mathrm{NO}_{3}$ and $\mathrm{NH}_{4}$ application levels. Increasing the 20:20:20 fertilizer concentration reduced the disease level from 82 to $96 \%$ with $\mathrm{N}$ at $180 \mathrm{mg}$ /liter to 6 to $10 \%$ with $\mathrm{N}$ at $720 \mathrm{mg} / \mathrm{liter}$. When either P, K, or ME was the sole variable, increasing concentrations had no significant effect on the disease, but elevating a mixed source nitrogen concentration from 0 to 180,360 , and $720 \mathrm{mg} / \mathrm{liter}$ (as $50 \%$ urea, $40 \% \mathrm{NH}_{4} \mathrm{NO}_{3}$, and $10 \% \mathrm{KNO}_{3}$ ) significantly reduced deformation similar to that observed with increasing concentrations of the 20:20:20 fertilizer. Among tested $\mathrm{N}$ sources, $\mathrm{NH}_{4}$ was the most effective in reducing the disease (almost to zero at an $\mathrm{N}$ concentration of $360 \mathrm{mg} / \mathrm{liter}$ ). Low disease incidence (0 to $10 \%$ ) was always associated with effluent $\mathrm{pH}$ of 6 or lower. Irrigating with acidified water (pH 5.5) in the presence of $\mathrm{N}$, as $\mathrm{NH}_{4}$ at $180 \mathrm{mg} /$ liter, additionally reduced disease from $56 \%$ under tap water $(\mathrm{pH} 7.8)$ irrigation to $11 \%$. Similar acidification in the presence of $\mathrm{NO}_{3}^{-} \mathrm{N}$ at $180 \mathrm{mg} /$ liter was ineffective in reducing the disease, but water basification in the presence of $\mathrm{NO}_{3}^{-} \mathrm{N}$ reduced disease incidence from 93 to $38 \% 90$ days after planting. The $\mathrm{N}$, $\mathrm{P}, \mathrm{K}, \mathrm{Fe}$, and $\mathrm{Zn}$ concentrations in gypsophila cuttings were similar under the three tested levels of $\mathrm{NH}_{4}, \mathrm{NO}_{3}$, and 20:20:20, whereas the concentration of $\mathrm{Mn}$ increased with increasing $\mathrm{N}$. The Mn concentration in cuttings was inversely correlated with disease and is probably an important factor to understanding the physiological background of the deformation disease.

Additional keywords: Fe, fertilizer, K, Mn, N, nitrogen forms, $\mathrm{P}, \mathrm{pH}, \mathrm{Zn}$.
The effects of plant nutrition in reducing disease incidence caused by soilborne pathogens have been widely reported $(4,6,8,10-13,21,22,29,34)$. Huber and Watson (13) observed that the incidence of several cortical and root diseases was reduced by $\mathrm{NO}_{3}^{-} \mathrm{N}$ and enhanced by $\mathrm{NH}_{4}^{-} \mathrm{N}$, but the responses in terms of mitigation of all diseases evaluated were inconsistent. Woltz and Magie (34) reported that high levels of N, regardless of source, increased Fusarium corm rot of gladiolus caused by $F$. oxysporum f. sp. gladioli. Spiegel and Netzer (29) demonstrated that muskmelon plants fertilized with $\mathrm{NH}_{4}^{-} \mathrm{N}$ showed more wilt caused by $F$. oxysporum f. sp. melonis, alone or in combination with the root-knot nematode Meloidogyne javanica, than those fertilized with $\mathrm{NO}_{3}^{-} \mathrm{N}$ applications; they also found that the $\mathrm{K}$ level had very little effect on these wilts. Schneider (25) related the inhibition of Fusarium yellows of celery in greenhouse and field experiments to $\mathrm{NO}_{3}^{-} \mathrm{N}$ and adding $\mathrm{KCl}$ reduced the disease further. Engelhard et al. (6) reported that $\mathrm{NO}_{3}^{-} \mathrm{N}$ decreased Fusarium wilt in tomato in comparison with $\mathrm{NH}_{4}^{-} \mathrm{N}$ and that liming the soil to a $\mathrm{pH}$ of 6.0 to 7.5 , in the absence of organic matter or $\mathrm{NH}_{4}^{-} \mathrm{N}$, decreased Fusarium wilt. The effects of soil $\mathrm{pH}$ and $\mathrm{NO}_{3}^{-} \mathrm{N}$ were additive in reducing Fusarium wilt in tomato and other crops (15). Huang and Kuhlman (10) reported that $\mathrm{N}$-fertilizers $\mathrm{Ca}\left(\mathrm{NO}_{3}\right)_{2}$,

Corresponding author: Y. Ben-Yephet; E-mail address: yephet@ volcani.agri.gov.il

DOI: 10.1094/PHYTO-96-0771

(C) 2006 The American Phytopathological Society
$\mathrm{NH}_{4} \mathrm{NO}_{3}$, $\left(\mathrm{NH}_{4}\right)_{2} \mathrm{SO}_{4}$, or urea affected colonization of pine stem segments by Rhizoctonia solani to various degrees; however, whereas $\left(\mathrm{NH}_{4}\right)_{2} \mathrm{SO}_{4}$ suppressed the incidence of damping-off more effectively than other $\mathrm{N}$-fertilizers, $\mathrm{NH}_{4} \mathrm{NO}_{3}$ enhanced it.

In Israeli nurseries, rooted cuttings of Gypsophila paniculata L. (baby's breath) planted in fumigated 0- to 8-mm tuff (Scoria) are used as mother plants to produce rooted cuttings for flower production. Harvesting of cuttings begins 4 to 5 weeks after planting (April to May) and continues until September to October. Although nurseries have traditionally relied on substrate fumigation, usually metham- $\mathrm{Na}$, to manage soilborne diseases, occasionally this treatment is not successful. A disease of unknown etiology in mother plants reduced the growth rate of cuttings and caused chlorotic leaves. As the disease severity increased, there was loss of apical control; this induced a broom-like growth of new cuttings that reduced the yield of cuttings as much as $50 \%$. We named this disease, deformation disease. In nurseries, disease incidence in mother plants appeared after several cycles of harvesting cuttings; usually 2 to 3 months after planting. Weekly harvesting of cuttings was one of the factors that enhanced expression of the disease. In our experimental study of organisms that might cause deformation disease, we eliminated the possible involvement of mites, nematodes, viruses, and phytoplasmas. When a naturally infested substrate was fumigated with either a fungicide or a bactericide before a new planting cycle of baby's breath mother plants, we were able to control the disease. Although we were unable to prove that specific organisms were 
involved, we had indirect proof for the involvement of both fungi and bacteria $(1,23)$. Involvement of organisms such as fungi, phytoplasmas, bacteria, mites, and aphids that may cause such abnormal growth has been widely reported in the literature. However, the only example to be proved was the involvement of Crinipellis perniciosa in the appearance of witches'-broom disease in cacao (Theobroma cacao) (7). In preliminary experiments in which baby's breath mother plants were fertilized weekly, we found that a twofold increase of the conventional concentration of a compound 20:20:20 fertilizer (raising the $\mathrm{N}$ concentration from 360 to $720 \mathrm{mg} / \mathrm{L}$ ) mitigated the incidence of this disease. The objective of the current study was to investigate the effects of the compound fertilizer and its components $(\mathrm{N}, \mathrm{P}, \mathrm{K}$, or microelements) on the incidence of deformation disease in $G$. paniculata mother plants planted in naturally infested substrates.

\section{MATERIALS AND METHODS}

Baby's breath rooted cuttings were planted in pairs in 10-liter buckets packed with naturally infested 0 - to 8 -mm black tuff (Scoria $=$ crushed volcanic stones $)$ or with steam-treated tuff in the control treatments. Tuff has a high $\mathrm{pH}$-dependent surface charge, and therefore, strongly buffers the solution $\mathrm{pH}$ (27). In all treatments (Table 1), nutrients were added manually with the water (1 liter per bucket) once a week. On the other days of the week, fresh or $\mathrm{pH}$-treated water was applied via two 1-liter/h emitters at a rate of 0.5 liter per bucket.

All experiments took place from June 1 to October 15 between 1998 and 2002 in a nethouse that provided 10\% shade. The daily mean outside air temperatures (maximum-minimum) during June, July, August, September, and October were 29.7 to 19.5, 31.9 to $22.2,32.4$ to $23,31.3$ to 20.9 , and 28.5 to $17.5^{\circ} \mathrm{C}$, respectively, with year-to-year fluctuations around the monthly mean not exceeding 7\%. Each treatment was replicated five times in a random block design, with each replicate comprising five buckets and two plants per bucket. Disease assessment and harvesting of cuttings were done weekly beginning 30 to 35 days after planting. Disease assessment recorded disease incidence and disease severity of mother plants. Disease severity was rated on a 0 to 3 scale. Level 0 corresponds to healthy cuttings with long, dark green leaves. At levels 1, 2, and 3, the growth rates of cuttings are reduced slightly, moderately, or severely, respectively, with enhanced leaf chlorosis as reduced growth rate. At levels 2 and 3, apical control was lost, and 2 or 3 , or more than 3 cuttings, respectively, emerged from each bud.

The ionic composition (mg/liter) of the fresh water was $58 \mathrm{Ca}$, $28 \mathrm{Mg}, 110 \mathrm{Na}$, and $220 \mathrm{Cl}$; the $\mathrm{HCO}_{3}$ concentration was $4.5 \mathrm{mM}$; the electric conductivity (EC) and $\mathrm{pH}$ were 1.1 and 7.8, respectively. The $\mathrm{Fe}, \mathrm{Zn}$, and $\mathrm{Mn}$ concentrations in solution were determined by atomic absorption, $\mathrm{K}$ determined by flame photometry, and $\mathrm{P}, \mathrm{NO}_{3}$, and $\mathrm{NH}_{4}$ determined with an auto-analyzer (32). To determine element concentrations in cuttings, plant tissue was oven dried at $65^{\circ} \mathrm{C}$, ground, and digested with $\mathrm{H}_{2} \mathrm{SO}_{4}+\mathrm{H}_{2} \mathrm{O}_{2}$ for $\mathrm{N}$ and $\mathrm{P}$ analysis and with $\mathrm{HNO}_{3}+\mathrm{HCLO}_{4}$ for cation analysis (9). Ion concentrations in water were determined as in the digest solutions. Summary of experiments and treatments appears in Table 1.

Statistical analysis. Analysis of variance was conducted on all data and the mean separation was provided by Duncan's multiple range test. Stepwise multiple regression analysis was used to correlate between disease incidence and growth factors. All analyses were performed using SAS version 6 (SAS Institute, Cary NC).

\section{RESULTS}

Effect of compound fertilizer (20:20:20) concentrations on disease incidence. Disease incidence was first observed 34 days after planting and reached its maximum 20 to 27 days later. Increasing the fertilizer $\mathrm{N}$ concentration from 0 to 180,360 , and $720 \mathrm{mg} /$ liter reduced disease incidence from $\sim 90 \%$ to $\sim 50,40$, and $\sim 10 \%$ on day 64 (mean of the two reported experiments) and similar effects were recorded on intermediate dates (Table 2). Even though experiment 1 was conducted between June and early August and experiment 2 conducted between August and early October, the effects of the treatments followed very similar trends, indicating that the seasonal effect was negligible. The correlation between disease incidence and disease severity was insignificant $\left(r^{2}\right.$ values vary between 0.59 and 0.67 ), which indicated that the relationship between the two was not related. Since the effects of treatments on disease incidence were better defined

TABLE 1. Summary of experiments and treatments over time

\begin{tabular}{|c|c|c|}
\hline Tested factor & Table no. (year) & Treatment description \\
\hline Concentration of a 20:20:20 + ME fertilizer ${ }^{\mathrm{u}}$ & $\begin{array}{r}2(1998 a) \\
(1998 b)\end{array}$ & $\begin{array}{l}\mathrm{N} \text { at } 0,180,360, \text { and } 720 \mathrm{mg} / \mathrm{liter} \\
\text { (repeated) }\end{array}$ \\
\hline Concentration of individual nutrients ${ }^{v}$ & $3(1999 a)$ & $\begin{array}{l}\mathrm{N} \text { at } 0,180,360 \text {, and } 720 \mathrm{mg} / \mathrm{liter}^{\mathrm{w}} \\
\mathrm{KH}_{2} \mathrm{PO}_{4} \text { at } 0,80,160 \text {, and } 320 \mathrm{mg} / \mathrm{liter} \\
\mathrm{KCl}-\mathrm{K} \text { at } 0,150,300 \text {, and } 600 \mathrm{mg} / \mathrm{liter} \\
\text { Microelements: Fe at } 0.45,0.90,1.80 \text {, and } 3.60 \mathrm{mg} / \text { liter }^{\mathrm{x}}\end{array}$ \\
\hline \multirow[t]{2}{*}{$\mathrm{N}$ source $\times \mathrm{N}$ concentration } & $4(1999 b)$ & $\begin{array}{l}\mathrm{N} \text { at } 180 \text { and } 720 \mathrm{mg} / \mathrm{liter} \text { as } 20: 20: 20 \\
\mathrm{~N} \text { at } 180 \text { and } 720 \mathrm{mg} / \mathrm{liter} \text { as } \mathrm{KNO}_{3} \\
\mathrm{~N} \text { at } 180 \text { and } 720 \mathrm{mg} / \mathrm{liter} \text { as } \mathrm{NH}_{4} \mathrm{NO}_{3} \\
\mathrm{~N} \text { at } 180 \text { and } 720 \mathrm{mg} / \mathrm{liter} \text { as urea } \\
\mathrm{N} \text { at } 180 \text { and } 720 \mathrm{mg} / \mathrm{liter} \text { as }\left(\mathrm{NH}_{4}\right)_{2} \mathrm{SO}_{4}\end{array}$ \\
\hline & $4(2000)$ & $\begin{array}{l}\mathrm{N} \text { at } 180 \text { and } 720 \mathrm{mg} / \mathrm{liter} \text { as } 20: 20: 20 \\
\mathrm{~N} \text { at } 180,360 \text {, and } 720 \mathrm{mg} / \mathrm{liter} \text { as } \mathrm{KNO}_{3} \\
\mathrm{~N} \text { at } 180 \text { and } 720 \mathrm{mg} / \mathrm{liter} \text { as urea } \\
\mathrm{N} \text { at } 180,360 \text {, and } 720 \mathrm{mg} / \mathrm{liter} \text { as }\left(\mathrm{NH}_{4}\right)_{2} \mathrm{SO}_{4}\end{array}$ \\
\hline \multirow[t]{2}{*}{$\mathrm{N}$ source $\times$ irrigation water $\mathrm{pH}^{\mathrm{y}}$} & $5(2001)$ & $\begin{array}{l}\text { pH } 5.5,7.8^{\mathrm{z}} \text {, and } 8.2 ; \mathrm{N} \text { at } 180 \mathrm{mg} / \mathrm{liter} \text { as }\left(\mathrm{NH}_{4}\right)_{2} \mathrm{SO}_{4} \\
\text { pH } 5.5,7.8^{\mathrm{z}} \text {, and } 8.2 ; \mathrm{N} \text { at } 180 \mathrm{mg} / \mathrm{liter} \text { as } \mathrm{KNO}_{3} \\
\text { pH } 5.5,7.8^{\mathrm{z}} \text {, and } 8.2 ; \mathrm{N} \text { at } 180 \mathrm{mg} / \mathrm{liter} \text { as } 20: 20: 20\end{array}$ \\
\hline & $6(2002)$ & $\begin{array}{l}\text { pH } 7.8^{z} \text { and } 8.6 ; \mathrm{N} \text { at } 180,360 \text {, and } 720 \mathrm{mg} / \mathrm{liter} \text { as } \mathrm{KNO}_{3} \\
\text { pH } 5.5 \text { and } 7.8^{\mathrm{z}} ; \mathrm{N} \text { at } 180,360 \text {, and } 720 \mathrm{mg} / \mathrm{liter} \text { as }\left(\mathrm{NH}_{4}\right)_{2} \mathrm{SO}_{4}\end{array}$ \\
\hline
\end{tabular}

\footnotetext{
u $\mathrm{N}$ composition: $50 \%$ urea, $40 \% \mathrm{NH}_{4} \mathrm{NO}_{3}$ and $10 \% \mathrm{KNO}_{3}$.

${ }^{v}$ Other nutrient concentrations as in 20:20:20 + ME at $720 \mathrm{mg} / \mathrm{liter} \mathrm{N}$.

${ }^{\mathrm{w}} \mathrm{N}$ composition as in 20:20:20 + ME.

${ }^{x}$ Microelements: $\mathrm{Fe} / \mathrm{Zn} / \mathrm{Mn}$ ratio $=0.05: 0.0125: 0.025$ as EDTA.

y Treated-water $\mathrm{pH}$ prior to irrigation (applied in each irrigation).

${ }^{\mathrm{z}}$ Fresh water $\mathrm{pH}$ prior to irrigation (applied in each irrigation).
} 
than their effect on disease severity data, only disease incidence was reported.

Effects of individual fertilizer ingredients on deformation disease. Elevating only the concentration of nitrogen (comprised of $50 \%$ urea- $\mathrm{N}, 40 \% \mathrm{NH}_{4} \mathrm{NO}_{3}^{-} \mathrm{N}$, and $10 \% \mathrm{KNO}_{3}^{-} \mathrm{N}$ ) in the irrigation water significantly reduced the disease. At the highest $\mathrm{N}$ concentration, disease incidence was reduced to a similar level (16.7\%), slightly higher than the 20:20:20 fertilizer. Elevating the concentrations of other fertilizer ingredients ( $\mathrm{P}, \mathrm{K}$, or ME) had no significant effect on disease incidence (Table 3).

Effects of nitrogen source on deformation disease and substrate leachate $\mathbf{p H}$. Disease incidence declined with increasing N regardless of the source; however, the effectiveness of the sources declined in the order of $\mathrm{NH}_{4}>$ urea $>20: 20: 20>\mathrm{NH}_{4} \mathrm{NO}_{3}>\mathrm{NO}_{3}$ (Table 4). As the $\mathrm{NH}_{4}$ and $\mathrm{NO}_{3}$ contents in the $\mathrm{N}$ solution increased, the leachate $\mathrm{pH}$ decreased, the effect being stronger with $\mathrm{NH}_{4}$ than with $\mathrm{NO}_{3}$. Since the $\mathrm{pH}$ was measured in leachate collected 2 days after the $\mathrm{N}$ source was added to the bucket, and in light of the high $\mathrm{pH}$ buffering capacity of the growth substrate (27), it is safe to conclude that the effects of the treatments on the actual $\mathrm{pH}$ at the root surface immediately after fertilization exceeded the above-mentioned effects on leachate $\mathrm{pH}$.

When the leachate $\mathrm{pH}$ under low $\mathrm{N}$ fertigation was reduced from 7.5 to 6.5, disease incidence in the urea and 20:20:20 fertilizer treatments was reduced from 70 to $49 \%$ and 93 to $54 \%$, respectively (Tables 4 and 5). The $\mathrm{pH}$ had a negligible effect in the presence of $\mathrm{NO}_{3}$ or $\mathrm{NH}_{4}$. Under high $\mathrm{N}$, decreasing the $\mathrm{pH}$ from 6.1 to 5.6 reduced disease incidence with all $\mathrm{N}$ sources (Table 4).

Effect of irrigation water $\mathbf{p H}$ on deformation disease. To elucidate the specific effect of $\mathrm{pH}$ on deformation disease, plants were irrigated daily with acidified ( $\mathrm{pH} 5.5)$ or fresh $(\mathrm{pH} 7.8)$ water at the lowest $\mathrm{N}$ concentration (180 mg/liter) (Table 5). In the presence of nitrate, acidified water had no effect on the disease compared with untreated fresh water, although the leachate $\mathrm{pH}$ was reduced to 6.3. Disease incidence was lower in plants fertilized with ammonium in untreated fresh water than with nitrate and fresh water, although the time-averaged leachate $\mathrm{pH}$ values were quite similar in both cases (7.4 and 7.9, respectively). Acidified water used in combination with $\mathrm{NH}_{4}$ decreased disease incidence further than the untreated fresh water irrigation over the entire growth period (128 days), although it was minimal when the leachate $\mathrm{pH}$ dropped below 6 . When acidified water was used with 20:20:20, disease incidence was reduced only if the leachate $\mathrm{pH}$ dropped to 6 or less (Table 5).

Raising the daily irrigation water $\mathrm{pH}$ from 7.8 to 8.6 decreased the disease 30 to $67 \%$ when the $\mathrm{N}$ source was nitrate (Table 6). Nitrate concentration in the water had only a small effect on dis- ease reduction. Elevation of the water $\mathrm{pH}$ had no effect on disease incidence when the $\mathrm{N}$ source was $\mathrm{NH}_{4}$, partly because the substrate $\mathrm{pH}$ could not be effectively raised (data not presented). When the daily water $\mathrm{pH}$ was lowered to 5.5 with $\mathrm{NH}_{4}$ as the $\mathrm{N}$ source, disease incidence was reduced further compared with that with fresh water, when $\mathrm{NH}_{4}$ was added at 180 and $360 \mathrm{mg} / \mathrm{liter}$, but not when it was added at $720 \mathrm{mg} / \mathrm{liter}$ when the disease incidence was the same as that with fresh or acidified water (Table 6).

Effects of nitrogen source and concentration on $\mathbf{N}, \mathbf{P}, \mathrm{K}$, and ME contents in Gypsophila cuttings. Increasing the $\mathrm{NO}_{3}$ concentration in irrigation water had no significant effect on $\mathrm{N}, \mathrm{P}, \mathrm{K}$, and $\mathrm{Ca}$ concentrations in tissues of the cuttings, but it reduced the concentration of $\mathrm{Mg}$ and increased $\mathrm{Fe}, \mathrm{Zn}$, and $\mathrm{Mn}$ in dried tissue. Increasing the $\mathrm{NH}_{4}^{-} \mathrm{N}$ concentration in the water had insignificant effects on the tissue $\mathrm{N}$ and $\mathrm{P}$ concentrations but increased tissue microelements, particularly Mn. The impact on Mn could plausibly be attributed to the pronounced reduction in leachate $\mathrm{pH}$. Increasing the 20:20:20 fertilizer concentration affected nutrient contents proportionally to the $\mathrm{NH}_{4}$ so that the overall effect was

TABLE 3. Effect of four rates of N, P, K, or microelement mixture (ME) constituting the 20:20:20 fertilizer on deformation disease in Gypsophila paniculata mother plants 64 days after planting compared with the complete 20:20:20 fertilizer

\begin{tabular}{lccccc}
\hline & \multicolumn{5}{c}{ Disease incidence (\%) } \\
\cline { 2 - 5 } & \multicolumn{4}{c}{ Ingredient } & Fertilizer \\
\cline { 2 - 5 } Concentration in water & $\mathrm{N}$ & $\mathrm{P}$ & $\mathrm{K}$ & $\mathrm{ME}$ & $20: 20: 20$ \\
\hline None & $98.5 \mathrm{a}^{\mathrm{x}}$ & 26.6 & 6.7 & 35.0 & $93.4 \mathrm{a}$ \\
Low $^{\mathrm{y}}$ & $82.8 \mathrm{a}$ & 23.4 & 2.8 & 50.0 & $93.4 \mathrm{a}$ \\
Medium & $61.3 \mathrm{~b}$ & 43.4 & 5.2 & 34.2 & $58.4 \mathrm{~b}$ \\
High & $16.7 \mathrm{c}$ & 10.0 & 4.0 & 30.8 & $11.6 \mathrm{~b}$ \\
Analysis of variance (ANOVA) & & & & \\
Mean & 64.8 & 25.9 & 4.7 & 37.5 & 43.8 \\
$F$ & 41.2 & 1.2 & 0.23 & 1.1 & 10.8 \\
$P R>F$ & 0.0001 & 0.36 & 0.87 & 0.39 & 0.0001 \\
LSD $^{\mathrm{z}}$ & 18.0 & 36.3 & 11.2 & 23.3 & 40.2 \\
\hline
\end{tabular}

${ }^{w} \mathrm{~N}, \mathrm{P}, \mathrm{K}$, and $\mathrm{Fe}$ concentrations at the low level were $180,80,150$, and 0.45 $\mathrm{mg} /$ liter, respectively. The concentrations in the medium and high levels were, respectively, twice and four times the low level. $\mathrm{N}$ sources in the $\mathrm{N}$ experiment were in the same proportions as in the 20:20:20 fertilizer mixture.

${ }^{x}$ Values in a given column marked with the same letter are not significantly different from each other according to Duncan's multiple range test at the $P=0.05$ probability level.

${ }^{\mathrm{y}}$ When N, P, K, or microelement was absent or at a reduced concentration, other constituents were present at the highest concentration. When 20:20:20 fertilizer was absent, irrigation was with fresh water only.

${ }^{z}$ LSD $=$ least significant difference.

TABLE 2. Effects of compound fertilizer (20:20:20 + ME) ${ }^{\mathrm{w}}$ rate (expressed as $\mathrm{N}$ concentration in water) on disease incidence in two successive experiments in Gypsophila paniculata mother plants planted in naturally infested tuff

\begin{tabular}{|c|c|c|c|c|c|c|c|c|c|c|}
\hline \multirow[b]{3}{*}{$\mathrm{N}$ (mg/liter) } & \multicolumn{10}{|c|}{ Disease incidence (\%) } \\
\hline & \multicolumn{5}{|c|}{ Experiment $1^{\mathrm{x}}$} & \multicolumn{5}{|c|}{ Experiment $2^{\mathrm{x}}$} \\
\hline & 34 & 42 & 49 & 57 & 64 & 34 & 42 & 49 & 57 & 64 \\
\hline 0 & $62.1 \mathrm{a}^{\mathrm{y}}$ & $65.4 \mathrm{a}$ & $69.3 \mathrm{a}$ & $84.7 \mathrm{a}$ & $86.3 \mathrm{a}$ & $81.5 \mathrm{a}$ & $81.7 \mathrm{a}$ & $91.3 \mathrm{a}$ & $98.3 \mathrm{a}$ & $96.3 \mathrm{a}$ \\
\hline 180 & $40.5 \mathrm{a}$ & $31.8 \mathrm{~b}$ & $33.3 \mathrm{~b}$ & $47.0 \mathrm{~b}$ & $35.9 \mathrm{~b}$ & $33.7 \mathrm{~b}$ & $36.2 \mathrm{~b}$ & $63.0 \mathrm{~b}$ & $76.2 \mathrm{ab}$ & $65.5 \mathrm{~b}$ \\
\hline 360 & $36.1 \mathrm{ab}$ & $31.7 \mathrm{~b}$ & $26.8 \mathrm{bc}$ & $35.4 \mathrm{~b}$ & $30.3 \mathrm{~b}$ & $29.8 \mathrm{~b}$ & $31.8 \mathrm{~b}$ & $48.0 \mathrm{~b}$ & $69.5 \mathrm{~b}$ & $48.8 \mathrm{~b}$ \\
\hline 720 & $9.8 \mathrm{~b}$ & $5.7 \mathrm{c}$ & $9.2 \mathrm{c}$ & $6.0 \mathrm{c}$ & $6.9 \mathrm{c}$ & $2.2 \mathrm{c}$ & $4.2 \mathrm{c}$ & $2.8 \mathrm{c}$ & $6.7 \mathrm{c}$ & $11.2 \mathrm{c}$ \\
\hline \multicolumn{11}{|c|}{ Analysis of variance (ANOVA) } \\
\hline Mean & 37.1 & 33.6 & 34.6 & 43.3 & 39.8 & 36.8 & 38.5 & 51.3 & 62.7 & 55.5 \\
\hline$F$ & 5.6 & 10.2 & 15.6 & 21.4 & 40.0 & 18.1 & 22.2 & 21.5 & 24.6 & 16.6 \\
\hline$P R>F$ & 0.009 & 0.0006 & 0.0001 & 0.0001 & 0.0001 & 0.0001 & 0.0001 & 0.0001 & 0.0001 & 0.0001 \\
\hline $\mathrm{LSD}^{\mathrm{z}}$ & 29.6 & 24.9 & 20.8 & 22.9 & 17.2 & 25.2 & 22.2 & 25.9 & 25.8 & 28.3 \\
\hline
\end{tabular}

w $20 \% \mathrm{~N}\left(50 \%\right.$ urea-N, $\left.40 \% \mathrm{NH}_{4} \mathrm{NO}_{3}^{-} \mathrm{N}, 10 \% \mathrm{KNO}_{3}^{-} \mathrm{N}\right), 20 \% \mathrm{P}_{2} \mathrm{O}_{5}, 20 \% \mathrm{~K}_{2} \mathrm{O}$, and $0.05 \% \mathrm{Fe}, \mathrm{Zn}$, and $\mathrm{Mn}$.

${ }^{x}$ Data collected at $34,42,49,57$, and 64 days after planting.

y Values in a given column marked with the same letter are not significantly different from each other according to Duncan's multiple range test at the $P=0.05$ probability level.

${ }^{\mathrm{z}} \mathrm{LSD}=$ least significant difference. 
less pronounced because of the $\mathrm{NO}_{3}$ present in the compound fertilizer (Table 7). To quantify the relationship between growth factors and disease incidence (DI [\%]), a multiple regression model between DI and measured leachate $\mathrm{pH}$ (within the $\mathrm{pH}$ range of 5.6 to 7.6) and nutrient concentrations in the plant tissue (Table 7) was calculated (Table 8). The regressions between growth factors and DI (Table 8) showed that leachate $\mathrm{pH}$ accounted for $87 \%$ of the total variability in disease incidence in the $\mathrm{pH}$ range of 5.6 to 7.6 (equation 1), and no other variable met the $P=0.150$ criterion of the model. When the solution $\mathrm{pH}$ was omitted from the multiple regression model, tissue $\mathrm{Mn}\left(T_{\mathrm{Mn}}\right)$ in the range 63 to $301 \mathrm{mg} / \mathrm{kg}$ was the factor best correlated with DI (equation 2). The second entrée into the model was $\left(T_{\mathrm{Mn}}\right)^{2}$ that accounted for another $13 \%$ of the total variability in DI.

\section{DISCUSSION}

In the current study, a twofold increase in the currently recommended fertilizer 20:20:20 dose reduced deformation disease incidence in $G$. paniculata mother plants growing in a naturally infested tuff (Scoria). The same effect could be achieved by increasing only the $\mathrm{N}$ concentration in the water. Increasing only the $\mathrm{P}, \mathrm{K}$, or microelement concentration had no effect on deformation disease. The effects of specific nutrients and their application rate on the incidence of various plant diseases are well documented $(3,22,24)$. Mineral nutrients reduce disease incidence either by direct toxic effects on the pathogen, by reducing susceptibility of the host, or by enhancing the population of antagonistic members of the soil microflora (13). Tenuta and Lazarovits (30) reported that nitrogenous amendments, such as meat and bone meal, kill sclerotia of the soilborne plant pathogen Verticillium dahliae through the ammonia and nitrous acid generated and that the effect depended on soil $\mathrm{pH}$. In general, sufficient ammonia was generated only in the presence of $\mathrm{NH}_{4}$ and a $\mathrm{pH}$ above 8, whereas nitrite or nitrous acid was produced in the presence of $\mathrm{NH}_{4}$ when the soil $\mathrm{pH}$ was below $6(2,8,18,19,21,24,26,28,31,33)$. In our current study, $\mathrm{NH}_{4}$ reduced disease incidence more efficiently than urea, $\mathrm{NH}_{4} \mathrm{NO}_{3}$, or $\mathrm{NO}_{3}$. The high efficacy of $\mathrm{NH}_{4}$ could, as inferred above, be attributed either to direct pathogen toxification by $\mathrm{NH}_{3}$ or nitrite or to indirect effects that involve enhanced crop resistance to pathogens, especially as a result of the increased uptake of Mn (Table 7) $(4,5,11,12)$. The observed reduction in $\mathrm{pH}$ is consistent with existing knowledge on the effects of nitrification and $\mathrm{NH}_{4}$ uptake on the release of protons $(14,20)$. A pH reduction was observed under $\mathrm{NO}_{3}$ nutrition also (Table 4), but in this case it was attributed to the accompanying $\mathrm{K}^{+}$that can replace the exchangeable $\mathrm{H}^{+}$and increase the cation-anion charge balance in the plant, with consequent $\mathrm{H}^{+}$excretion into the soil solution (20).

The finding that disease incidence at any $\mathrm{NH}_{4}$ concentration could be reduced by acidifying the irrigation water (Table 6) supports the hypothesis that solution $\mathrm{pH}$ was a predominant factor in reducing disease incidence. Notably, even when there was relatively little change in $\mathrm{pH}$, a considerable difference in disease was observed between plants supplied with ammonium or nitrate; this

TABLE 4. Effects of nitrogen source on the rate of disease incidence (DI) and respective pot leachate $\mathrm{pH}$ values ${ }^{\mathrm{w}}$ in Gypsophila paniculata mother plants 56 days after planting

\begin{tabular}{|c|c|c|c|c|c|c|c|c|c|c|}
\hline \multirow{3}{*}{$\begin{array}{l}\text { Nitrogen } \\
\text { source }^{\mathrm{x}}\end{array}$} & \multicolumn{4}{|c|}{ Experiment 1 (1999) } & \multicolumn{6}{|c|}{ Experiment 2 (2000) } \\
\hline & \multicolumn{2}{|c|}{ N (180 mg/liter) } & \multicolumn{2}{|c|}{ N (720 mg/liter) } & \multicolumn{2}{|c|}{ N (180 mg/liter) } & \multicolumn{2}{|c|}{$\mathrm{N}$ (360 mg/liter) } & \multicolumn{2}{|c|}{ N (720 mg/liter) } \\
\hline & DI $(\%)$ & $\mathrm{pH}$ & DI (\%) & $\mathrm{pH}$ & DI $(\%)$ & $\mathrm{pH}$ & $\mathrm{DI}(\%)$ & $\mathrm{pH}$ & DI $(\%)$ & $\mathrm{pH}$ \\
\hline $20: 20: 20$ & $93.4 \mathrm{a}^{\mathrm{y}}$ & 7.6 & $16.6 \mathrm{bc}$ & 6.1 & $54.0 \mathrm{ab}$ & $6.4 \mathrm{~b}$ & - & - & $0 \mathrm{~b}$ & $5.5 \mathrm{~b}$ \\
\hline $\mathrm{NO}_{3}$ & $70.0 \mathrm{ab}$ & 7.7 & $25.0 \mathrm{a}$ & 6.2 & $65.8 \mathrm{a}$ & $6.7 \mathrm{a}$ & $54.2 \mathrm{bc}$ & $6.3 \mathrm{~d}$ & $3.4 \mathrm{a}$ & $5.8 \mathrm{a}$ \\
\hline $\mathrm{NH}_{4} \mathrm{NO}_{3}$ & $64.7 \mathrm{~b}$ & 7.5 & $20.0 \mathrm{~b}$ & 6.1 & - & - & - & - & - & - \\
\hline Urea & $70.2 \mathrm{ab}$ & 7.7 & $16.2 \mathrm{c}$ & 6.2 & $49.0 \mathrm{~b}$ & $6.3 \mathrm{bc}$ & - & - & $5.0 \mathrm{a}$ & $5.7 \mathrm{a}$ \\
\hline $\mathrm{NH}_{4}$ & $28.0 \mathrm{c}$ & 7.4 & $2.2 \mathrm{~d}$ & 6.0 & $29.4 \mathrm{c}$ & $6.3 \mathrm{bc}$ & $0 \mathrm{~d}$ & $6.0 \mathrm{e}$ & $0 \mathrm{~b}$ & $5.4 \mathrm{~b}$ \\
\hline \multicolumn{11}{|c|}{ Analysis of variance (ANOVA) } \\
\hline Mean & 65.3 & 7.6 & 15.6 & 6.1 & 49.6 & 6.5 & - & - & 2.8 & 5.7 \\
\hline$F$ & 14.2 & & 14.2 & & 16.6 & 39.3 & - & - & 7.8 & 12.8 \\
\hline$P R>F$ & 0.001 & & 0.001 & & 0.001 & 0.006 & - & - & 0.05 & 0.009 \\
\hline $\mathrm{LSD}^{\mathrm{z}}$ & 25.6 & & 8.2 & & 12.2 & 0.25 & - & - & 2.6 & 0.24 \\
\hline
\end{tabular}

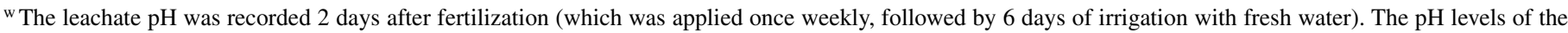
irrigation solutions with the various fertilizers in treatments were 6.5 with the 20:20:20 fertilizer, 5.8 with $\mathrm{NO}_{3}, 6.3$ with urea and 6.3 with $\mathrm{NH}_{4}$.

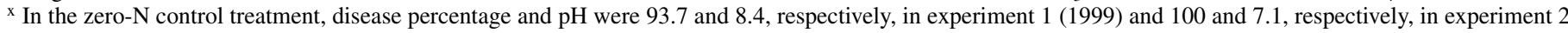
(2000).

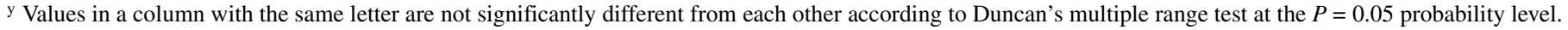

${ }^{\mathrm{z}}$ LSD $=$ least significant difference.

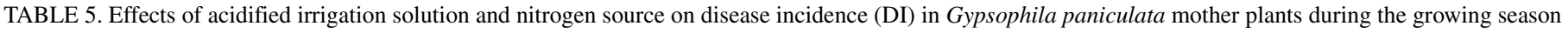

\begin{tabular}{|c|c|c|c|c|c|c|c|}
\hline \multirow[b]{2}{*}{ Nitrogen source ${ }^{\mathrm{x}}$} & \multirow[b]{2}{*}{ Irrigation water $\mathrm{pH}$} & \multicolumn{2}{|c|}{57 Days } & \multicolumn{2}{|c|}{100 Days } & \multicolumn{2}{|c|}{128 Days } \\
\hline & & DI $(\%)$ & Leachate $\mathrm{pH}$ & DI $(\%)$ & Leachate $\mathrm{pH}$ & DI $(\%)$ & Leachate $\mathrm{pH}$ \\
\hline $20: 20: 20$ & 7.8 & $70.0 \mathrm{ab}^{\mathrm{y}}$ & $8.0 \mathrm{a}$ & $95.0 \mathrm{a}$ & $7.6 \mathrm{a}$ & $95.0 \mathrm{a}$ & $7.6 \mathrm{~b}$ \\
\hline $20: 20: 20$ & 5.5 & $82.5 \mathrm{ab}$ & $6.8 \mathrm{c}$ & $57.5 \mathrm{~b}$ & $6.0 \mathrm{~d}$ & $50.0 \mathrm{~b}$ & $5.8 \mathrm{~d}$ \\
\hline $\mathrm{NO}_{3}$ & 7.8 & $82.5 \mathrm{ab}$ & $7.8 \mathrm{a}$ & $100.0 \mathrm{a}$ & $7.9 \mathrm{a}$ & $100.0 \mathrm{a}$ & $7.9 \mathrm{a}$ \\
\hline $\mathrm{NO}_{3}$ & 5.5 & $87.5 \mathrm{a}$ & $6.3 \mathrm{~d}$ & $97.5 \mathrm{a}$ & $6.4 \mathrm{c}$ & $97.5 \mathrm{a}$ & $6.2 \mathrm{c}$ \\
\hline $\mathrm{NH}_{4}$ & 7.8 & $65.0 \mathrm{ab}$ & $7.5 \mathrm{~b}$ & $50.0 \mathrm{~b}$ & $6.9 \mathrm{~b}$ & $55.0 \mathrm{~b}$ & $7.4 \mathrm{~b}$ \\
\hline $\mathrm{NH}_{4}$ & 5.5 & $45.0 \mathrm{~b}$ & $6.5 \mathrm{~d}$ & $12.5 \mathrm{c}$ & $5.8 \mathrm{~d}$ & $10.0 \mathrm{c}$ & $5.9 \mathrm{~d}$ \\
\hline \multicolumn{8}{|c|}{ Analysis of variance (ANOVA) } \\
\hline Mean & & 72.1 & 7.15 & 68.9 & 6.8 & 67.9 & 6.8 \\
\hline$F$ & & 1.9 & 43.4 & 24.4 & 59.3 & 57.3 & 136 \\
\hline$P R>F$ & & 0.46 & 0.0001 & 0.0001 & 0.0001 & 0.001 & 0.0001 \\
\hline $\mathrm{LSD}^{\mathrm{z}}$ & & 38.3 & 0.30 & 23.4 & 0.37 & 42 & 0.26 \\
\hline
\end{tabular}

${ }^{\mathrm{x}} \mathrm{N}$ concentration in the water (applied once a week) was $180 \mathrm{mg} / \mathrm{liter}$.

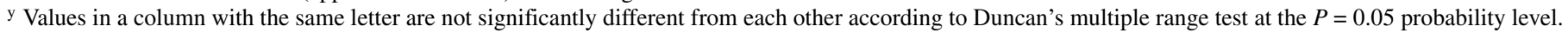

${ }^{\mathrm{z}}$ LSD $=$ least significant difference. 
difference increased as $\mathrm{pH}$ declined (Table 4). This indicates that the impact of reduced $\mathrm{pH}$ on disease could be fully expressed in the presence of $\mathrm{NH}_{4}$ but not of $\mathrm{NO}_{3}$ (e.g., at $\mathrm{pH} \sim 6$ and $\mathrm{N}$ at 360 $\mathrm{mg} / \mathrm{liter}$, disease incidence in the presence of $\mathrm{NO}_{3}$ or $\mathrm{NH}_{4}$ was 54.2 or 0 , respectively, Table 4). This may be related to the fact that at soil $\mathrm{pH}<7$, the second stage of nitrification is inhibited (16), causing nitrite accumulation in the system (21). The biocidal effect of nitrite (21) may provide additional mitigation that cannot be achieved in the presence of nitrate. The decreased $\mathrm{pH}$ might also have a directly adverse effect on pathogenic bacteria, otherwise it would not be effective in the presence of nitrate. Alternatively, it might mediate the dissolution of sparsely soluble minerals, particularly $\mathrm{P}$ and $\mathrm{Mn}$ (17), and thus increase their uptake by plants. The present data shows that $\mathrm{NH}_{4}$ did not stimulate $\mathrm{N}, \mathrm{P}$,

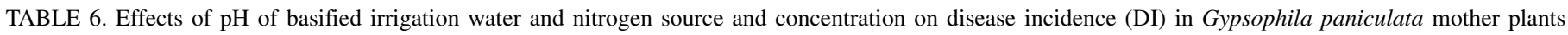
during the growing season

\begin{tabular}{|c|c|c|c|c|c|c|c|c|c|c|}
\hline \multirow[b]{2}{*}{ N source ${ }^{\mathrm{X}}$} & \multirow[b]{2}{*}{$\mathrm{N}$ (mg/liter) } & \multirow{2}{*}{$\begin{array}{l}\text { Irrigation } \\
\text { water } \mathrm{pH}\end{array}$} & \multicolumn{2}{|c|}{48 Days } & \multicolumn{2}{|c|}{61 Days } & \multicolumn{2}{|c|}{77 Days } & \multicolumn{2}{|c|}{90 Days } \\
\hline & & & $\mathrm{DI}(\%)$ & Leachate $\mathrm{pH}$ & DI $(\%)$ & Leachate $\mathrm{pH}$ & DI $(\%)$ & Leachate $\mathrm{pH}$ & DI (\%) & Leachate $\mathrm{pH}$ \\
\hline $\mathrm{NO}_{3}$ & 180 & 7.8 & $75.6 \mathrm{ab}^{\mathrm{y}}$ & $7.3 \mathrm{c}$ & $82.5 \mathrm{ab}$ & $7.6 \mathrm{bc}$ & $89.8 \mathrm{ab}$ & $7.5 \mathrm{~d}$ & $93.5 \mathrm{a}$ & $7.6 \mathrm{c}$ \\
\hline $\mathrm{NO}_{3}$ & 180 & 8.6 & $33.0 \mathrm{c}$ & $8.0 \mathrm{a}$ & $61.2 \mathrm{bc}$ & $8.2 \mathrm{a}$ & $56.4 \mathrm{bc}$ & $8.3 \mathrm{a}$ & $37.6 \mathrm{e}$ & $8.3 \mathrm{a}$ \\
\hline $\mathrm{NO}_{3}$ & 360 & 7.8 & $85.0 \mathrm{a}$ & $7.2 \mathrm{c}$ & $94.6 \mathrm{a}$ & $7.3 \mathrm{c}$ & $97.1 \mathrm{a}$ & $7.2 \mathrm{e}$ & $94.6 \mathrm{a}$ & $7.4 \mathrm{~cd}$ \\
\hline $\mathrm{NO}_{3}$ & 360 & 8.6 & $51.4 \mathrm{~b}$ & $7.8 \mathrm{ab}$ & $45.3 \mathrm{c}$ & $8.1 \mathrm{ab}$ & $45.6 \mathrm{c}$ & $8.0 \mathrm{~b}$ & $49.2 \mathrm{~d}$ & $8.2 \mathrm{ab}$ \\
\hline $\mathrm{NO}_{3}$ & 720 & 7.8 & $57.8 \mathrm{~b}$ & $7.1 \mathrm{c}$ & $70.1 \mathrm{~b}$ & $7.2 \mathrm{c}$ & $68.4 \mathrm{~b}$ & $7.0 \mathrm{e}$ & $75.3 \mathrm{~b}$ & $7.1 \mathrm{~d}$ \\
\hline $\mathrm{NO}_{3}$ & 720 & 8.6 & $25.0 \mathrm{~cd}$ & $7.6 \mathrm{~b}$ & $25.4 \mathrm{~cd}$ & $7.7 \mathrm{~b}$ & $26.2 \mathrm{~d}$ & $7.8 \mathrm{c}$ & $8.3 \mathrm{f}$ & $8.0 \mathrm{~b}$ \\
\hline $\mathrm{NH}_{4}$ & 180 & 7.8 & $33.6 \mathrm{c}$ & $6.5 \mathrm{~d}$ & $49.9 \mathrm{c}$ & $6.5 \mathrm{e}$ & $54.1 \mathrm{c}$ & $6.4 \mathrm{f}$ & $56.2 \mathrm{c}$ & $6.4 \mathrm{e}$ \\
\hline $\mathrm{NH}_{4}$ & 180 & 5.5 & $5.0 \mathrm{~d}$ & $6.1 \mathrm{e}$ & $17.5 \mathrm{~d}$ & $5.9 \mathrm{f}$ & $17.9 \mathrm{de}$ & $5.7 \mathrm{~g}$ & $10.7 \mathrm{f}$ & $5.8 \mathrm{f}$ \\
\hline $\mathrm{NH}_{4}$ & 360 & 7.8 & $10.0 \mathrm{~d}$ & $5.8 \mathrm{f}$ & $17.5 \mathrm{~d}$ & $5.9 \mathrm{f}$ & $47.2 \mathrm{~cd}$ & $5.6 \mathrm{~g}$ & $12.3 \mathrm{f}$ & $5.4 \mathrm{~g}$ \\
\hline $\mathrm{NH}_{4}$ & 360 & 5.5 & $2.9 \mathrm{~d}$ & $5.4 \mathrm{~g}$ & $5.0 \mathrm{de}$ & $5.0 \mathrm{~g}$ & $13.3 \mathrm{e}$ & $5.0 \mathrm{~h}$ & $0 \mathrm{~g}$ & $5.0 \mathrm{~h}$ \\
\hline $\mathrm{NH}_{4}$ & 720 & 7.8 & $4.0 \mathrm{~d}$ & $4.8 \mathrm{~h}$ & $0 \mathrm{e}$ & $4.5 \mathrm{~h}$ & $10.0 \mathrm{e}$ & $4.3 \mathrm{i}$ & $0 \mathrm{~g}$ & $4.2 \mathrm{i}$ \\
\hline $\mathrm{NH}_{4}$ & 720 & 5.5 & $2.9 \mathrm{~d}$ & $4.7 \mathrm{~h}$ & $0 \mathrm{e}$ & $4.7 \mathrm{~h}$ & $5.7 \mathrm{e}$ & $4.5 \mathrm{i}$ & $0 \mathrm{~g}$ & $4.3 \mathrm{i}$ \\
\hline \multicolumn{11}{|c|}{ Analysis of variance (ANOVA) } \\
\hline Mean & & & 33.0 & 6.5 & 39.1 & 6.5 & 44.3 & 6.4 & 36.5 & 6.5 \\
\hline$F$ & & & 7.5 & 10.5 & 10.8 & 93.5 & 9.0 & 134.8 & 17.3 & 212.6 \\
\hline$P R>F$ & & & 0.0001 & 0.0001 & 0.0001 & 0.0001 & 0.0001 & 0.0001 & 0.0001 & 0.0001 \\
\hline $\mathrm{LSD}^{\mathrm{z}}$ & & & 14.8 & 0.16 & 13.7 & 0.18 & 14.0 & 0.16 & 11.9 & 0.14 \\
\hline
\end{tabular}

$\mathrm{x} \mathrm{N}$ concentration in water (applied once a week) as indicated.

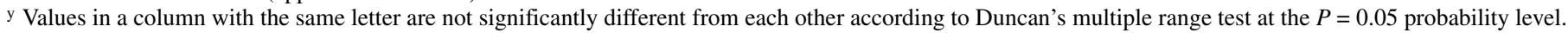

${ }^{\mathrm{z}}$ LSD $=$ least significant difference.

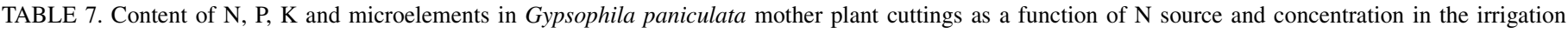
water ${ }^{\mathrm{w}}$, the corresponding leachate $\mathrm{pH}^{\mathrm{x}}$, and disease incidence

\begin{tabular}{|c|c|c|c|c|c|c|c|c|c|c|c|}
\hline \multirow[b]{2}{*}{$\mathrm{N}$ source } & \multirow[b]{2}{*}{$\mathrm{N}$ (mg /liter) } & \multicolumn{8}{|c|}{ Macro and microelement content } & \multirow[b]{2}{*}{$\begin{array}{c}\text { Leachate } \\
\text { pH }\end{array}$} & \multirow{2}{*}{$\begin{array}{c}\text { Disease } \\
\text { incidence } \\
(\%)\end{array}$} \\
\hline & & $\begin{array}{c}\mathrm{N} \\
(\mathrm{g} / 100 \mathrm{~g})\end{array}$ & $\begin{array}{c}\mathrm{P} \\
(\mathrm{g} / 100 \mathrm{~g})\end{array}$ & $\frac{\mathrm{K}}{(\mathrm{g} / 100 \mathrm{~g})}$ & $\begin{array}{c}\mathrm{Ca} \\
(\mathrm{g} / 100 \mathrm{~g})\end{array}$ & $\begin{array}{c}\mathrm{Mg} \\
(\mathrm{g} / 100 \mathrm{~g})\end{array}$ & $\begin{array}{c}\mathrm{Fe} \\
(\mathrm{mg} / \mathrm{kg})\end{array}$ & $\begin{array}{c}\mathrm{Zn} \\
(\mathrm{mg} / \mathrm{kg})\end{array}$ & $\begin{array}{c}\mathrm{Mn} \\
(\mathrm{mg} / \mathrm{kg})\end{array}$ & & \\
\hline $\mathrm{NO}_{3}$ & 180 & $4.5 \mathrm{bcd}^{\mathrm{y}}$ & $0.66 \mathrm{ab}$ & $4.2 \mathrm{abc}$ & $1.8 \mathrm{ab}$ & $0.65 \mathrm{ab}$ & $197 \mathrm{~cd}$ & $78 \mathrm{~d}$ & $65 \mathrm{~d}$ & 6.7 & 65.8 \\
\hline $\mathrm{NO}_{3}$ & 360 & $4.8 \mathrm{bc}$ & $0.68 \mathrm{ab}$ & $4.3 \mathrm{abc}$ & $1.9 \mathrm{ab}$ & $0.59 \mathrm{ab}$ & $250 \mathrm{bcd}$ & $103 \mathrm{bcd}$ & $115 \mathrm{~cd}$ & 6.5 & 54.2 \\
\hline $\mathrm{NO}_{3}$ & 720 & $4.7 \mathrm{bcd}$ & $0.68 \mathrm{ab}$ & $4.0 \mathrm{bcd}$ & $1.8 \mathrm{ab}$ & $0.47 \mathrm{c}$ & $353 \mathrm{ab}$ & $118 \mathrm{ab}$ & $202 \mathrm{~b}$ & 5.8 & 3.4 \\
\hline $\mathrm{NH}_{4}$ & 180 & $4.3 \mathrm{~d}$ & $0.67 \mathrm{ab}$ & $4.7 \mathrm{a}$ & $1.6 \mathrm{ab}$ & $0.65 \mathrm{ab}$ & $309 \mathrm{abc}$ & $104 \mathrm{bcd}$ & $151 \mathrm{bc}$ & 6.2 & 29.4 \\
\hline $\mathrm{NH}_{4}$ & 360 & $4.4 \mathrm{~cd}$ & $0.59 \mathrm{~b}$ & $4.2 \mathrm{bc}$ & $1.8 \mathrm{ab}$ & $0.60 \mathrm{ab}$ & $268 \mathrm{bcd}$ & $106 \mathrm{bc}$ & $184 \mathrm{~b}$ & 5.7 & 0 \\
\hline $\mathrm{NH}_{4}$ & 720 & $4.7 \mathrm{bcd}$ & $0.63 \mathrm{ab}$ & $3.8 \mathrm{~cd}$ & $1.6 \mathrm{~b}$ & $0.55 \mathrm{bc}$ & $428 \mathrm{a}$ & $135 \mathrm{a}$ & $301 \mathrm{a}$ & 5.6 & 0 \\
\hline $20: 20: 20$ & 180 & $4.5 \mathrm{~cd}$ & $0.64 \mathrm{ab}$ & $3.5 \mathrm{~d}$ & $1.8 \mathrm{ab}$ & $0.62 \mathrm{ab}$ & $161 \mathrm{~d}$ & $83 \mathrm{~cd}$ & $63 d$ & 7.6 & 93.4 \\
\hline $20: 20: 20$ & 360 & $5.3 \mathrm{a}$ & $0.69 \mathrm{ab}$ & $4.6 \mathrm{ab}$ & $2.1 \mathrm{a}$ & $0.69 \mathrm{a}$ & $165 \mathrm{~d}$ & $75 \mathrm{~d}$ & $105 \mathrm{~cd}$ & 6.8 & 58.4 \\
\hline $20: 20: 20$ & 720 & $4.9 \mathrm{ab}$ & $0.71 \mathrm{a}$ & 4.4abc & $1.4 \mathrm{~b}$ & $0.56 \mathrm{bc}$ & $281 \mathrm{bcd}$ & $100 \mathrm{bcd}$ & $179 \mathrm{~b}$ & 6.1 & 11.6 \\
\hline \multicolumn{12}{|c|}{ Analysis of variance (ANOVA) } \\
\hline Mean & & 4.7 & 0.66 & 4.2 & 1.8 & 0.60 & 268 & 100 & 152 & & \\
\hline$F$ & & 4.8 & 1.3 & 4.0 & 1.7 & 3.3 & 3.9 & 4.6 & 13.1 & & \\
\hline$P R>F$ & & 0.0006 & 0.78 & 0.002 & 0.36 & 0.007 & 0.002 & 0.0009 & 0.0001 & & \\
\hline $\mathrm{LSD}^{\mathrm{z}}$ & & 0.46 & 0.104 & 0.64 & 0.52 & 0.12 & 148 & 30 & 110 & & \\
\hline
\end{tabular}

${ }^{\mathrm{w}}$ Tissue samples and $\mathrm{pH}$ values were taken from plants in treatments in Table 4 for $\mathrm{NO}_{3}$ and $\mathrm{NH}_{4}$ and from Table 3 for 20:20:20.

${ }^{\mathrm{x}}$ Leachate $\mathrm{pH}$ was measured the second day after fertilization.

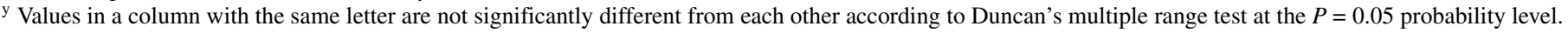

${ }^{\mathrm{z}} \mathrm{LSD}=$ least significant difference.

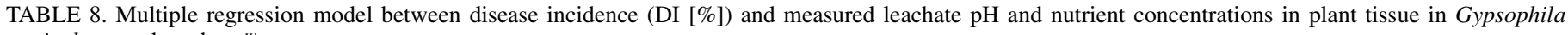
paniculata mother plants ${ }^{\mathrm{w}}$

\begin{tabular}{|c|c|c|c|c|c|c|c|c|}
\hline \multirow[b]{2}{*}{ Equation } & \multirow[b]{2}{*}{$X^{\mathrm{x}}$} & \multicolumn{3}{|c|}{ Coefficient values } & \multicolumn{3}{|c|}{$F$} & \multirow[b]{2}{*}{$R^{2}$} \\
\hline & & $\mathrm{a} 1^{\mathrm{y}}$ & $\mathrm{a} 2^{\mathrm{y}}$ & $b^{y}$ & $\mathrm{a} 1^{\mathrm{z}}$ & $\mathrm{a} 2^{\mathrm{z}}$ & $\mathrm{b}^{\mathrm{z}}$ & \\
\hline 1 & $\mathrm{pH}$ & $46.78 \pm 6.95$ & $\ldots$ & $261.1 \pm 44.3$ & $45.2 * *$ & $\ldots$ & $34.8 * * *$ & 0.87 \\
\hline 2 & $T_{\mathrm{Mn}}$ & $-0.377 \pm 0.076$ & $\ldots$ & $92.4 \pm 12.8$ & $24.5^{* *}$ & $\ldots$ & $52.4 * * *$ & 0.78 \\
\hline 3 & $T_{\mathrm{Mn}}$ & $-1.028 \pm 0.028$ & $0.00187 \pm 6.4 \mathrm{E}-4$ & $138.6 \pm 18.1$ & $20.5 * *$ & $8.6^{*}$ & $58.8 * * *$ & 0.91 \\
\hline
\end{tabular}

${ }^{\mathrm{w}}$ The general regression equation is $\mathrm{DI}=\mathrm{a} 1 X+\mathrm{a} 2 X^{2}+\mathrm{b}$ where $X$ is defined in the table.

${ }^{x}$ Range in $\mathrm{pH}$ is 5.6 to 7.6 and in $T_{\mathrm{Mn}}$ (Mn concentration in plant tissue) is 63 to $301 \mathrm{mg} / \mathrm{kg}$.

$\mathrm{y} \pm$ Standard error.

$\mathrm{z} *, * *$, and $* * *=$ significant difference at $P=0.05,0.01$, and 0.001 , respectively. 
and $\mathrm{K}$ uptake, but it significantly elevated the Mn concentration in the tissues of cuttings (Table 7). Increasing the $\mathrm{NH}_{4}$ concentration in irrigation water enhanced this effect, plausibly by further depressing substrate solution $\mathrm{pH}$.

In the experimental growth substrate used in the current study, the $\mathrm{pH}$ of the leachate could be elevated above that of fresh water ( $\mathrm{pH} 7.8$ ) only in the presence of $\mathrm{NO}_{3}$, which naturally stimulates $\mathrm{OH}^{-}$release by roots $(20)$. When the leachate $\mathrm{pH}$ exceeded 8 , disease incidence significantly declined and the impact was enhanced as the nitrate concentration increased (Table 6). When nitrate increases, the ratio between the $\mathrm{OH}^{-}$content in the rhizosphere and the entire substrate volume increases; therefore, similar leachate $\mathrm{pH}$ values may be associated with enhancing disease reduction. This presumption would be true if pathogen activity were more effective in the rhizosphere than in bulk soil.

We suggest that the mechanism by which high $\mathrm{pH}(>7.8)$ reduces disease involves ammonia release in the soil. The tuff substrate includes a small quantity of organic matter and at a $\mathrm{pH}>8$, the $\mathrm{NH}_{4}$ released via mineralization is sufficient to produce toxic $\mathrm{NH}_{3}$ at a concentration sufficient to kill or inhibit soil microorganisms (2).

The regressions between growth factors and DI (Table 8) showed that the two factors that best correlated with DI were substrate solution (leachate) $\mathrm{pH}$ (equation 1) and tissue $\mathrm{Mn}$ concentration (equations 2 and 3 ). The equations indicate that leachate $\mathrm{pH}$ was the main factor suppressing DI. The high correlation between $T_{\mathrm{Mn}}$ and DI cannot answer the question whether Mn was instrumental in suppressing the disease or not.

To summarize, we suggest that the following factors and mechanisms determine disease incidence: (i) increasing the application rates of $\mathrm{NO}_{3}$ and $\mathrm{NH}_{4}$ reduced DI because of the reduction in substrate $\mathrm{pH}$; (ii) the reduced $\mathrm{pH}$ (from 7.8 to 5.6) increased the uptake and tissue concentration of $\mathrm{Mn}$ and this could have reduced DI when $\mathrm{pH}$ was within the above range; (iii) decreasing soil $\mathrm{pH}$ also caused nitrite accumulation that further suppressed the disease, the fact that this effect was $\mathrm{NH}_{4}$-specific explains why, under a similar $\mathrm{pH}, \mathrm{NH}_{4}$ was more effective than $\mathrm{NO}_{3}$ in reducing the DI; and (iv) increasing the substrate (leachate) $\mathrm{pH}$ from $\sim 7.5$ to 8.3 (possible only at low and intermediate $\mathrm{NO}_{3}$ concentrations) caused release of ammonia. This requires the presence of a small concentration of $\mathrm{NH}_{4}$ such as could be obtained from tuff or root debris. The biocidal effect of $\mathrm{NH}_{3}$ was obtained despite a decrease in plant Mn concentration stemming from the high $\mathrm{pH}$. The wide range of effects that were carefully controlled and monitored in this study is consistent with the diversity of the published data on crop resistance to root pathogens under a variety of environmental conditions.

\section{LITERATURE CITED}

1. Ben-Yephet, Y., Reuven, M., Mor, I., Szmulewich, Y., Lampel, M., Zviebil, A., Gera, A., and Gerzon, U. 1998. New disease in mother plants of Gypsophila paniculata reduces production of cuttings and control of this disease. (Hebrew) Dappe Meda 11:63-66.

2. Ben-Yephet, Y., Tsror, L., Reuven, M., Gips, A., Bar, Z., Einstein, A., Turjeman, Y., and Fine, P. 2005. Effect of Ecosoil and $\mathrm{NH}_{4}$ in controlling soilborne pathogens. Acta Hortic. 698:115-121.

3. Chun, D., and Lockwood, L. 1985. Reductions of Pythium ultimum, Thielaviopsis basicola, and Macrophomina phaseolina populations in soil associated with ammonia generated from urea. Plant Dis. 69:154-158.

4. Graham, R. D. 1983. Effect of nutrient stress on susceptibility of plants to disease with particular reference to the trace elements. Adv. Bot. Res. 10:221-276.

5. Elmer, W. H. 1995. Association between Mn-reducing root bacteria and $\mathrm{NaCl}$ application in suppression of Fusarium crown and root rot of asparagus. Phytopathology 85:1461-1467.

6. Engelhard, A. W., Jones, J. P., and Woltz, S. S. 1989. Nutritional factors affecting Fusarium wilt incidence and severity. Pages 332-352 in: Vascular Wilt Diseases of Plants. Vol. H28. E. C. Tjamos and C. Beckman, eds. NATO ASI Series, Springer-Verlag, Berlin, Heidelberg.
7. Evans, C. C. 1978. Witches' broom disease of cocoa (Crinipellis pernici$o s a$ ) in Ecuador, I. The fungus. Ann. Appl. Biol. 89:185-192.

8. Gilpetrick, J. D. 1969. Role of ammonia in the control of avocado root rot with alfalfa meal soil amendment. Phytopathology 59:973-978.

9. Hardy, G. W. (ed.) 1967. Soil testing and plant analysis, part II. SSSA special publication No 2, Soil Sci. Soc. Am. Madison, Wis.

10. Huang, J. W., and Kuhlman, E. G. 1991. Formulation of a soil amendment to control damping-off of slash pine seedlings. Phytopathology 81:163-170.

11. Huber, D. M. 1991. The use of fertilizers and organic amendments in the control of plant disease. Pages 405-494 in: Handbook of Pest Management in Agriculture. Vol. 1, 2nd ed. D. Pimentel, ed. CRC Press, Boca Raton, FL.

12. Huber, D. M., and Graham, R. D. 1999. The role of nutrition in crop resistance and tolerance to diseases. Pages 169-204 in: Mineral Nutrition of Crops, Fundamental Mechanisms and Implications. Z. Rengel, ed. The Haworth Press, London.

13. Huber, D. M., and Watson, R. D. 1974. Nitrogen form and plant disease. Annu. Rev. Phytopathol. 12:139-165.

14. Imas, P., Bar-Yosef, B., Kafkafi, U., and Ganmore-Newman, R. 1997. Release of carboxylic anions and protons by tomato roots in response to ammonium-nitrate ratio and $\mathrm{pH}$ in nutrient solution. Plant Soil 35:35-39.

15. Jones, J. P., and Woltz, S. S. 1975. Effect of liming and nitrogen source on Fusarium wilt of cucumber and watermelon. Proc. Fla. State Hortic. Soc. 88:200-203.

16. Lang, H. J., and Elliott, G. C. 1991. Influence of ammonium:nitrate ratio and nitrogen concentration on nitrification activity in soilless potting media. J. Am. Soc. Hortic. Sci. 116:642-645.

17. Lindsy, W. L. 1979. Chemical Equilibration in Soils. John Wiley, New York.

18. Loffler, H. J. M., Cohen, E. B., Oolbekkink, G. T., and Shippers, B. 1986. Nitrite as a factor in the decline of Fusarium oxysporum f. sp. dianthi in soil supplemented with urea or ammonium chloride. Neth. J. Plant Pathol. 92:153-162.

19. Loffler, H. J. M., Koelman, A., Nielander, H. A. B., and Shippers, B. 1986. Reduced chlamydospore formation and enhanced lysis of chlamydospores of Fusarium oxysporum in soil with added urea and ammonium chloride. Biol. Fer. Soils 2:1-6.

20. Marschner, H. 1995. Mineral Nutrition of Higher Plants. 2nd ed. Academic Press, London.

21. Michel, V. V., and Mew, T. W. 1998. Effect of soil amendment on the survival of Ralstonia solanacearum in different soils. Phytopathology 88:300-305.

22. Punja, Z. K., and Grogan, R. G. 1982. Effects of inorganic salts, carbonate-bicarbonate anions, ammonia, and modifying influence of $\mathrm{pH}$ on sclerotial germination of Sclerotium rolfsii. Phytopathology 72:635-639.

23. Reuven, M., Zviebil, A., Szmulewich, Y., Kleitman, F., Manulis, S., and Ben-Yephet, Y. 1999. Causal organisms of deformation disease in Gypsophila paniculata mother plants. Phytoparasitica 27:149.

24. Rush, C. M., and Lyda, S. D. 1982. Effects of anhydrous ammonia on mycelium and sclerotia of Phymatotrichum omnivorum. Phytopathology 72:1085-1089.

25. Schneider, R. W. 1985. Suppression of Fusarium yellows of celery with potassium, chloride and nitrate. Phytopathology 75:40-48.

26. Sequeira, L. 1963. Effect of urea applications on survival of Fusarium oxysporum f. cubense in soil. Phytopathology 53:332-336.

27. Silber, A., Bar-Yosef, B., Singer, A., and Chen, Y. 1994. Mineralogical and chemical composition of pyroclastic rocks from Mt Peres in northern Israel. Geoderma 63:123-144.

28. Smiley, R. W., Cook, R. J., and Papendick, R. I. 1970. Anhydrous ammonia as a soil fungicide against Fusarium and fungicidal activity in the ammonia retention zone. Phytopathology 60:1227-1232.

29. Spiegel, Y., and Netzer, D. 1984. Effect of nitrogen form at various levels of potassium on the Meloidogyne-Fusarium wilt complex in muskmelon. Plant Soil 81:85-92.

30. Tenuta, M., and Lazarovits, G. 2002. Ammonia and nitrous acid from nitrogenous amendments kill the microsclerotia of Verticillium dahliae. Phytopathology 92:255-264.

31. Tsao, P. H., and Oster, J. J. 1981. Relation of ammonia and nitrous acid to suppression of Phytophthora in soils amended with nitrogenous organic substances. Phytopathology 71:53-59.

32. U.S. Environment Protection Agency. 1984. Methods for chemical analysis of water and wastes. EPA-600/4-79-020. Environmental Monitoring and Support Laboratory, Office of Research and Development, Cincinnati, $\mathrm{OH}$.

33. Wodzinski, R. S., Labeda, D. P., and Alexander, M. 1978. Effects of low concentrations of bisulfite-sulfite and nitrite on microorganisms. Appl. Environ. Microbiol. 35:718-723.

34. Woltz, S. S., and Magie, R. O. 1975. Gladiolus Fusarium disease reduction by soil fertility adjustments. Proc. Fla. State Hortic. Soc. 88:559-562. 